\title{
THE PLANETARY GARDEN. WHERE NATURAL AND HUMAN INTERTWINE
}

\author{
Ramón PICO* \\ University of Seville, Hisoria, Teork̦a y Composición Arquitectónicas, \\ C/ Lucero, 2, Seville, 41003 Spain
}

Received 13 November 2015; accepted 4 October 2016

\begin{abstract}
Spring 1935. After twenty-five years of fascination for heights and six of flying, stimulating experiences, Le Corbusier published Aircraft, a real "Manifesto for a New Era", according to his own words. Even though Vers une architecture had limited the aeronaoutic model validity to the framework of housing and easthetics ten years before, the reference then was expanded to the city and its fitting within the natural framework, to the definition of a new global habitat in which public space became the focus.

The flying experience allowed him to look into the past and find the subtle balance of man and nature. Revelation and rebellion at the same time. Thanks to the new visual as well as mental perspective provided by height, he would drive his reflections towards "geoarchitecture", a definitive, Humboldtian approach to Earth.

His aerial observation of the Algerian M'Zab valley or the layout of the settlements along the Paraná crystallised both into texts such as Sur les quattro routes, Aircraft or Les trois établissements humains, and a series of proposals for Rio, São Paulo, Montevideo, Buenos Aires and Algiers. Epic adventures through which, and connecting with the interest of those geographers worried about reclaiming human action on the writing on the Earth through his "establishments", Le Corbusier tackled the configuration of a new public space beyond the limits of the traditional city, claiming for a new planetary order.
\end{abstract}

Keywords: contemporary architecture, geoarchitecture, Le Corbusier, public space, heritage, historical landscape.

\section{Introduction}

This contribution addresses the relevance of the flying experience in Le Corbusier, whom tackled the configuration of a new public space beyond the limits of the traditional city, claiming for a new planetary order, and connecting with the interest of those geographers worried about reclaiming human action on the writing on the Earth through his "establishments". The research has been supported on the review of the recent literature on city, landscape and aeronautics, mainly the contibutions of Boyer, Duempelmann, Morshed or Waldheim, and the study of Le Corbusier's original texts.

\section{In no heart is there room for another}

Those were the first words that Marinetti was able to pronounce after his first flying experience (Marinetti 1968: 136). Hardly had a decade elapsed since the Wright brothers achieved to take flight when the creed of the aeronautic good news firmly spread out over the European capitals, attracting all types of curious people, among whom the names of restless personalities such as Kafka, Melnikov, Le Corbusier or Marinetti could be found.

The new flying devices that challenged the law of gravity were ultralight, flimsy machines of unusual shapes and amazingly magical. Their capacity to provide stimulus could spread in different directions: the attraction to their new geometries, the morbid intoxication of benzene odours, the roaring engines, the propellers fast movement and, of course, the exciting experience provided by height. Marinetti's words are deeply expressive when he recalled his aerial baptism in his texts and how "his chest opened up like a great hole into which the entire horizon of the sky flowed deliciously, smooth, fresh, torrential". Marinetti felt "the ferocious and flushing massage of the crazy wind..." how, on descending... "you've triumphed over the trap of the road. You've triumphed over the law which forces man to crawl" (De Maria 1968: 35). Emotions, adrenaline shakes, categorically described by

${ }^{*}$ Corresponding author. E-mail: rpico@us.es 


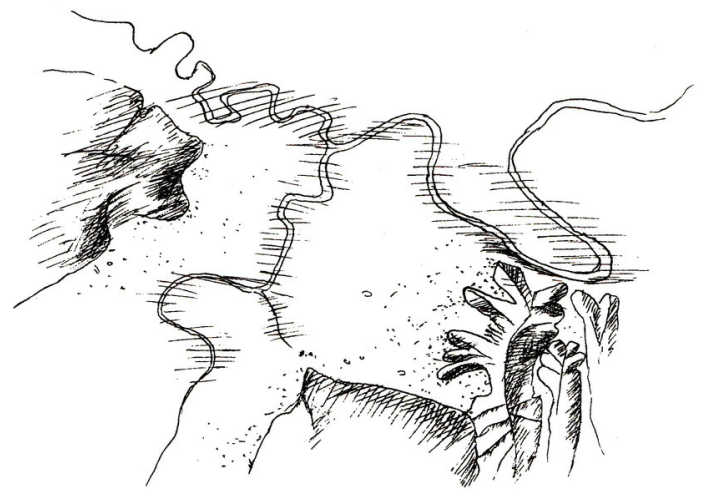

Fig. 1. Le Corbusier, Aircraft, (1935). Figure 116: "Another is our destiny"

Kafka when, after descending from an aircraft in Brescia, he wrote: "in no heart is there room for another" (Kafka 1909: 47).

They were isolated experiments which found their way in the cultivated plots of the peri-urban areas to progressively conquer the heart of the cities. Le Corbusier was already present in these first approaches and he described, especially moved, the encounter that took place on the outskirts of Paris in May 1909 (Le Corbusier 1935). After that day, Le Corbusier had multiple approaches to the fascinating world of aeronautics, always on the ground, until the opportunity to experiment the overwhelming, stimulating experience of flying finally appeared in 1929. From that moment on, his notebooks reflected lots of flights over M'Zab, Asunción, Tempelhoff or Rio de Janeiro; drawings which built up a complete atlas of experiences, reflections and life lessons from above (Fig. 1).

The revelations provided by the surface of the Earth quickly generated a double effect on the restless architect: on the one hand, regarding the consolidated city, this new perspective allowed Le Corbusier to reinforce the appreciation of the leading role of open spaces; on the other hand, and with respect to the territory beyond the cities, it brought to light the subtle balance natural-artificial and it emphasised the potential of open spaces as the backbone of an urban model destined to spread wildly all over the planet (Fig. 2) (Brenner, Schmid 2015).

\section{From South America to Algiers, flying experiences.}

These revelations emerged above all after the flights over South America in 1929 (Boyer 2003; Gutiérrez 2009; Collins 1995) and over Algiers in 1933. The former particularly contributed to acknowledging the cohesive function of natural spaces, domesticated by man and transformed into gardens beyond the traditional city, whereas in the latter Le Corbusier clearly interpreted the organisational role of open spaces, both public and private, in the inner configuration of the historical settlements of M'Zab.

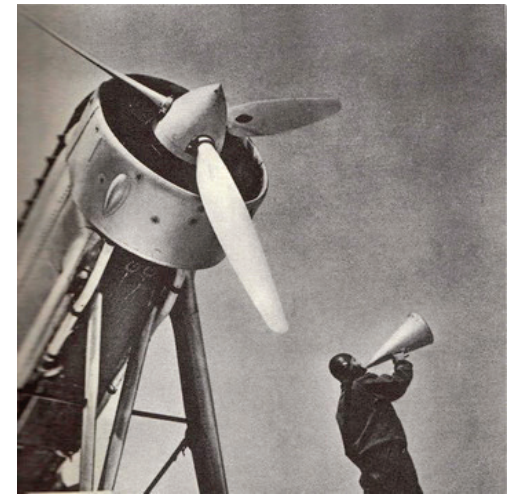

Fig. 2. Le Corbusier, Aircraft, (1935). Figure 56: “A Revolution in the suitable moment. The truth expels ugliness. A new Era"

In October 1828 Le Corbusier had already received his aerial baptism on a Paris-Berlin-Moscow journey, but this flight experience could well have been an event to forget. In October in Central Europe, flying conditions turned really unfavourable: reduced visibility, movements, shakes, were part of the usual experiences on the journeys at that time. On the contrary, the experience must have been very different in the American spring. He flew on a brand-new Latécoére 28, recently brought for the inauguration of the new line, enjoying the best conditions to fly.

Besides, the circumstances surrounding the flight were also attractive as he got in contact with a peculiar pilot of the company: Antoine Saint-Exupéry (1900-1944). Both were explorers, adventurers who exchanged their perceptions about the force exerted by the South-American natural landscapes, the emotion of human life on the ground or the new ways opened by aerial view. These exchanges could have been influential on the telegraphic writing present in Le Corbusier's sketches (Pedretti 1987, Gutiérrez 2009). It was also the beginning of their friendship and mutual admiration which continued two years later when they met again exploring the Algerian desert, and reached its highest point with the inclusion of Saint-Exupéry into Le Corbusier's personal aviation Olympus in Sur les quatre routes: "Saint-Exupéry is also a deserving companion of those calm heroes". (Le Corbusier 1941: 11)

On November 1st, Le Corbusier got onboard the Late 28 in Buenos Aires, (Gutiérrez; González 2009) notebook in hand and stimulating Saint-Exupéry sitting next to him. What he discovered was a fascinating landscape: the plain got transformed. The way to Asunción was a territory ruled by the meanders of the Paraná, a place where water and land tonalities appeared together with shapes modelled by both nature and human action: geographies.

The flight was slow and the scenery invited reflection: a stroll in the sky. It evolved almost like a film sequence, unveiling a new type of explorer (Colomina 1994; Duempelmann 2014; Morshed 2015; Waldheim, Duempelmann 2016). Le Cobursier, moved, witnessed the spectacle of nature: the course of the rivers, the arrangement 
of human establishments, the sense of their bonds,... the landscape built by human action. It was then that he recognized all that man missed due to his limitations as a terrestrial animal: "when (...) one has entered the intimacy of the city, when one has torn away in a single glance of the gliding bird all the secrets that it hid so easily from the poor terrestrial on his two feet, one has seen everything, understood everything" (Le Corbusier 1930: 259).

The American sky went through absolute transformation. Le Corbusier spent the twenty-two days on his way back to Europe on the Lusitania almost literally locked up in his cabin, still excited after nearly three months of continuous discoveries. The goal: to produce a text with which he would try to place himself as the "master" of mature proposals, very different from that of "radical innovator" that he had embodied ten years before (Cohen 1993; Boyer 2003: 96).

Le Corbusier rewrote in Precisions the talks presented during his South-American tour (Rojo de Castro 2008), but in this redefinition of the text it will not be just the values and circumstances of the discovered territory that allow blurring the ideas of vehement Le Corbusier. In this case, the physical medium was not innocuous but definitely decisive to undertand such excitement. Le Corbusier, who had dreamt of flying strolls since he was eighteen, at last received a nice aerial baptism. He fulfilled one of his greatest dreams and witnessed, in especially favourable conditions, a visual spectacle in which the power of American nature revealed in all its fullness. The human being's relationships, conflicts, helplessness, conquests and achievements over the natural medium were exposed all of a sudden.

The Law of the Meander was added later into the text of the sixth talk, that has been held six days before of his flight over the Parana river. It was the perfect metaphor of the end of the mechanical tyranny and the opening to a new lyrical poetry, the magical encounter of man with nature. On coming across insurmountable obstacles, nature acted in an intelligent way, forcing the straight flow to distort.

An emotional, perceptive shake such as the contemplation of the powerful American geography from the upper view of the sky turned therefore definitive in the city planner's subsequent career. From then on, his ideas for the city's new models gushed out from a deeply phenomenological position: "The non-professional aeronaut (with the mind gone blank) remains thoughtful: he only finds shelter in himself and his works. But once he has come down to the Earth, his goals and determinations acquire a new scope" (Le Corbusier 1935: 22).

Four years later, a new flying experience caught his attention to the role of free spaces inside the cities, the observation field being in this case the Algerian Chebka of the M'Zab, a pentapolis made of five ksar wrapped in a winding vegetal ribbon. This had been one of the issues that drew the attention of the greatest nineteenth century French geographers, interested in overcom- ing the merely physical understanding of geography. Among them, Jean Brunhes (1869-1930), who included in his Human Geography a number of references to this territory, to which he assigned the concept of human island (Brunhes 1910).

Nine centuries before, this inhospitable territory had been the Mozabites' destination after leaving Sedrata to take up exile two hundred kilometres to the east, to die in the desert. There they chose a network of dry rivers, domesticated it by digging wells in the rock, planting date palm trees, wrapping five nearby towns in a big garden: Ghardaïa, Beni Isguen, Melika, Bounora and El Atteuf. All in all, the ideal setting to make Bruhnes and the like defend the transforming action carried out by man over the medium.

Without a doubt, these geography manuals of the time were a travel guidebook for Le Corbusier, who was always interested in reading about territory and anthropology. In fact, during his first period in Paris, between 1908 and 1909, he already attended the Sorbonne classrooms where Vidal de la Blache (1845-1918) or Bruhnes himself lectured about Human Geography.

His interest for geography and the evolution of human communities also brought him close to other personalities attracted by approaching human action over the physical medium, namely historian Gaston Roupnel (1871-1946), geographer Marcel Mercier (1876-1954), whose text "La civilisation urbaine a M'zab" he would annotate in detail, or anthopologist, ethnologist and aviator Marcel Griaullé (1898-1956), a pioneer in the use of aerial photography in the thirties, cited by Le Corbusier in L'urbanisme des trois établissements humains: "Limit is a matter of gods and not a matter of men".

His first contact with this land took place in spring 1931, a brief experience that led him to meet with Antoine Saint-Exupéry again in Bou-Saada (Bunkse 1990). Both of them went deep into the desert and they were charmed by the incredible shapes of a landscape of sand dunes where abstraction and the tones of the relief were magically crowned by the astonishing human constructions (Gerber 1992).

That very summer, he decided to go back on holiday, in what Francesco Tentori has called the "second trip to the East". After driving through Spain and Morocco in his Voisin $14 \mathrm{HP}$, he finally adventured 650 kilometres into the south of Algiers in search of M'Zab valley. In this first encounter with M'Zab, on the ground, he discovered, pleasantly surprised, the ochre landscape with white and blue cubes in the sun, the amazing architecture of Ghardaia mosque or the role of minarets in the urban landscape. He contemplated the Oasis of the summer towns and, moved, transmitted the experience. (Le Corbusier 1931: 92) Its value, like the American meander, lay in an encounter of efforts which avoided meachnical linearity, in the huge collaborative work in which nature, its management by man and time had done everything. 
Nevertheless, opposed to the privilege of the oasis, the $k s a r$, the winter city appeared as a dramatic place. The visit, carried out in the worst period to walk around its streets, left a bittersweet taste in Le Corbusier: "... it looked like real hell. There were only narrow, sloping streets, cavity walls, impossibility" (Le Corbusier 1935: 12).

Worried about it, Le Corbusier decided to go back to examine the city from above and repeat the gratifying American experience in this land, trying to definitively find out what happened behind those opaque walls and understand how a solid city with hardly any public spaces could function. After hearing about the Aéroclub d'Algerie, he set out to go on a second trip to M'Zab in March 1933, with the ideal conditions to look from above.

The pilot Louis Durafour (1888-1967) and the architect set off at midday on Saturday 17th March from Algiers airport - Casa Blanchemer. The conditions of the visual flight forced them to spend the night in Laghouat and then leave for Ghardaïa early on Sunday. The experience of a flight at sunrise was sublime: clean air, dim light, long shadows, short journeys... conditions that allowed Le Corbusier to complete a notebook full of drawings so valuable that some of them were in the demanding selection of Aircraft two years later.

From the air Le Corbusier clearly perceived how the vegetal serpent made by the palm trees embraced compact single bodies inside such as Berriane, Guerrara or Beni Isguen, characterised by "The absolute unity of all the houses". Ghardaïa ksar was without a doubt the most significant, when the pilot approached it and spiraled over the minarete as noted down in a brief sketch: "Durafour, piloting his small aircraft, pointed at two spots in the horizon, 'Look! There are the cities!' Then, like a hawk, he went down over one of them several times. This is how I could discover the principle that governs the cities of the M'Zab valley. The aircraft had revealed it all, and what we saw was a great lesson for us" (Le Corbusier 1935: 12).

The experience can clearly be summarised through analysing the accounts of events provided by Le Corbusier in Aircraft. In his report he remembered his first encounter with M'Zab as one full of confusion and disappointment, after examining it from the ground in 1931. However, he emotionally described the revelation brought about by his experience during the flight in 1933 and how he actually had only understood the Mozabite human islands from above as, thanks to the aircraft, he discovered the miracle of the M'Zab cities' inner life hidden away from the visitor by the opaque street walls: "Behind the blind street walls happy houses opened. Each one of them to a delightful garden through three wide arches (...) Every house in M'Zab, without exception, is a place of calm life happiness" (Le Corbusier 1935: 12).

Thanks to the flight's sublime experience, Le Corbusier recognised the possibilities of transition spaces in the Arab city, of inner gardens which established the perfect gradient between public and private space. Hidden behind the impervious garden walls of those "clay canals" that made up the ksar streets, they set the first approach level to the home privacy, a necessary filter, forgotten at times, in the proposals for the new city.

\section{Proposals from the air}

Throughout the exciting stage of human habitat discovery from the air between 1928 and 1935, Le Corbusier would always get on the aircraft notebook in hand: "On the aircraft I took my sketchbook and was drawing as I saw everything clear" (Le Corbusier 1930: 260).

It is obvious that the change in perspective supplied by height allowed him to make large scale proposals, with an immediate, impressive approach to the place, heady at times (Monteys 2004). During the flight Le Corbusier worked on a huge living model and it was almost inevitable that ideas gushed out because, as he remarked, "when one has become the gliding bird flying at length over the city, ideas strike you" (Le Corbusier 1930: 259).

It was impossible for the town planner to grasp enough knowledge of the specific problems of each place at a small scale, like street or district, in such a short time, but the zoom provided by the aircraft allowed him to approach the problem in its widest terms, efficiently leading the proposals towards the territorial dimension between 1929 and 1931: Seascraper for Montevideo, Groundscraper for São Paulo, inhabited areas which interacted with the scenery in Rio or Algiers (Framptom 1980; Tsiomis 1998).

In opposition to the new colonial metropolis, it was of paramount importance for Le Corbusier to understand the human habitat, the atmosphere, the context, and the interaction with the natural elements, meanders, woods, dunes, marshlands or cliffs, which reached an extraordinary dimension in these lands.

Under these circumstances, between 1929 and 1935, Le Corbusier undertook the making of his well-known proposals for Buenos Aires, Rio de Janeiro (Fig. 3), São Paulo and Algiers. These proposals could not be understood from the simple binary reduction between the ground-breaking, avant-garde architect and that focusing on historical vernacular traditions; or between the Platonic idealist and that enticed by the efficient pragmatism of technology and engineering. The action carried out in Rio de Janeiro is likely to be the one that best allows us to understand the scope of those proposals that tend to be comprehensive of a wide territorial and social reality, of a complex habitat.

Far beyond the conventional principles pointed out by some authors, referring to mainstream urban matters, such as traffic reduction in the city centre, the rise of the population density or the extension of means of transport, the proposal showed or confirmed interests such as the increase of public green areas or the appearance of the megalomaniac building-viaduct that synthesized the operation.

The possibility of restructuring the existing city by means of a colossal area of infrastructures, the buildingviaduct, gained geographic dimension only understandable 


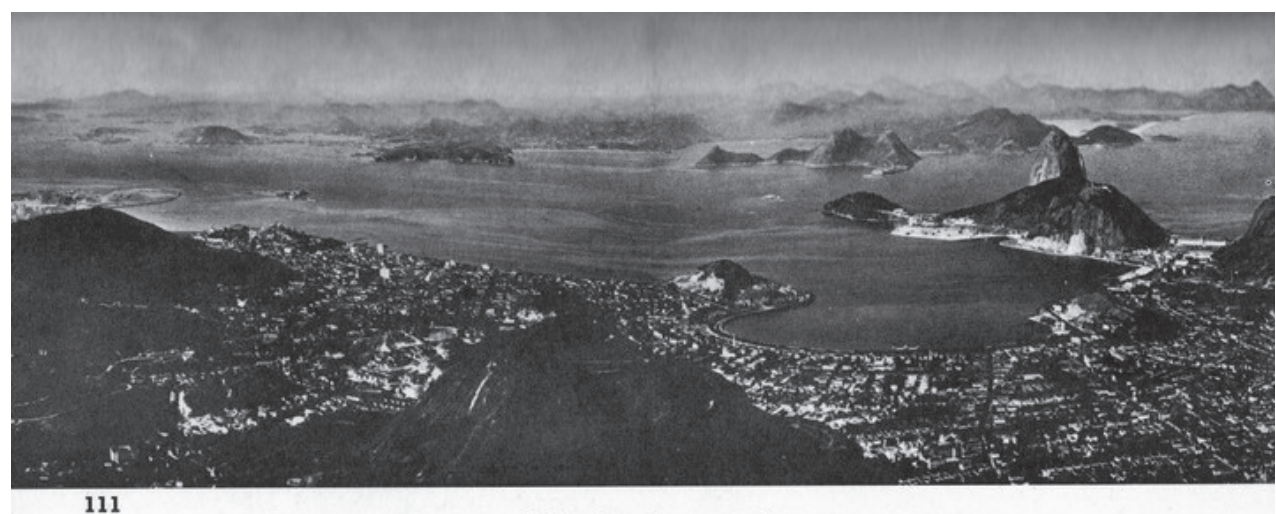

111

Río de Janeiro, totalmente encerrada.

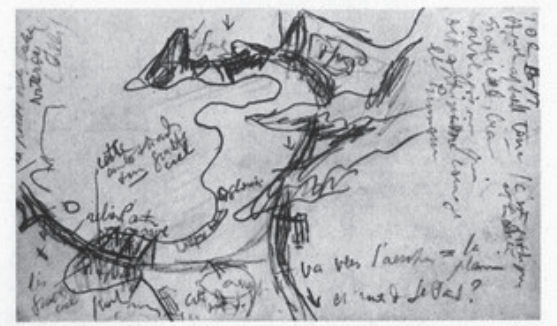

112

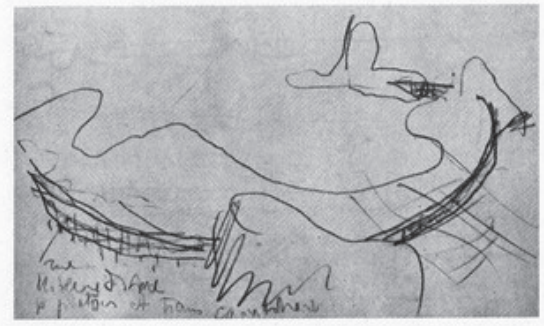

Dos esbozos realizados durante un vuelo en 1929, en el momento en que la idea de un vasto programa de urbanismo orgánico acudió a mi como una revelación.

Fig. 3. Le Corbusier, Aircraft, (1935). Figures 111 y 112: "two sketches made during a flight in 1929, at the time that the idea of a vast program of organic urbanism came to me as a revelation"

from above, and it also added new values to the medium. The first aim was to enrich the human habitat by adding dialectic layers to that medium, through an urban project that did not interfere with the existing city, overlapping past and present as strata of the same history. An inhabited six-kilomentre-long, one-hundred-metre-high viaduct was the chosen formula (Fig. 4).

The viaduct shape posed us a second but not less relevant question: the proposal intended to relate the geographic references of the place as well as the most important urban landmarks with a natural territory which amassed both the indigenous world's relics and some extraordinary natural values, necessary ingredients for the territory-city's new public space (Sequeira 2012).

\section{Geoarchitecture}

These proposals to generate new complex habitats, together with reflections expressed by Le Corbusier in texts like Aircraft or Sur les quatre routes were included in an intense geographic debate which, since the fall of the Old Order, had been made patent about the landscape. This was viewed at the beginning in merely naturalist terms, a real and symbolic expression of the peoples and nations, of men and their associations.

Landscapes were connected with the lifestyles of the people who interacted in those landscapes, but also with their ways of thinking and feeling, with their inner horizons. There were, according to Humboldt, "mysterious analogies and moral harmonies that unite man with the external world" (Humboldt 1845: 4).
In the early twentieth century, the emergence of the aircraft proved decisive for the development of this debate, opening a sequence of events which would result in the convention to understand the landscape as human construct at the end of the twentieth century (Maderuelo 2008).

The aircraft was the tool that allowed setting a distant viewpoint, from which the human work disappeared or was perceived in geometric abstraction. From the aircraft, the view became Humboldtian, natural and human intertwined and "detail records which characterise the Trip to the East are replaced by geographic notes about rivers, estuaries,

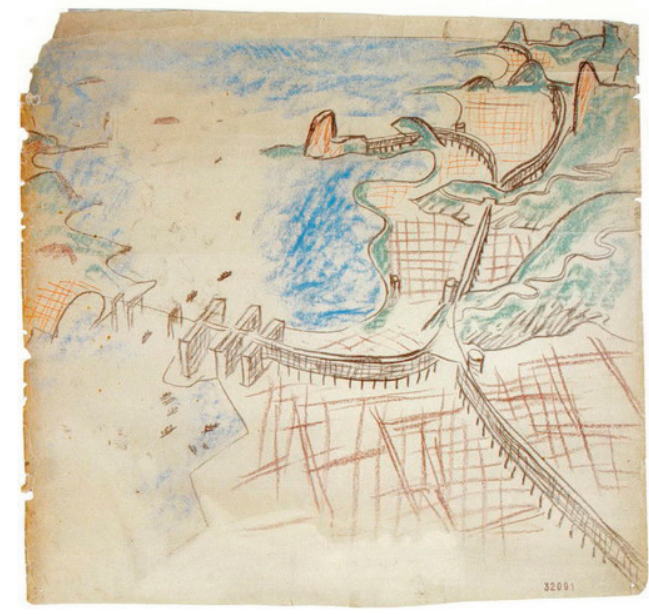

Fig. 4. Le Corbusier. Rio de Janeiro aerial view 1929, (C) FLC ADAGP 32091 
clouds and sunrises" (Liernur 2008; Sachs 1995). From this moment, as Boyer pointed out, for restless spirits like Le Corbusier, the freedom of perception given by aerial mobility and the vertiginous capacity to go round the planet transfigured his thought (Fig. 5).

The aerial experiences were not the ultimate reason for the change undergone by a mature Le Corbusier's career in the thirties, but we can actually percieve these flights as one of the main motives that led the machinist architect to integration and openness areas. These saw the growth of the Association pour une Rénovation Architectural (ASCORAL), created in Paris in 1942, chaired by him, in a time that witnessed how the amazing aerial atlases made by Deffontaines, Chombart de Lauwe (Fig. 6) or Martonne began to circulate successfully among researchers and laypeople.

After the experience of ASCORAL profound meetings, held once a fortnight all throughout one year, the outcome was the publication of Les trois établissements humains. The title of this text kept the key that allowed us to understand Le Corbusier's position near the geographic discipline when he turned to a concept like "establishment" often defined and used by personages like Jean Bruhnes, who resorted to it in his attempt to defend the value of Human Geography.

The introduction started with the usual dramatic analysis of the modern city, a recurring element in the architect's texts. In this case he showed a new, wider view, the way the airplane indicted the city in Aircraft (Fig. 7). From this exceptional observatory Le Corbusier equated modern cities with vast deserts, where sand gave its place to pavements and motor vehicles, where the exodus to satellite cities and suburbs only brought bigger circulation problems.

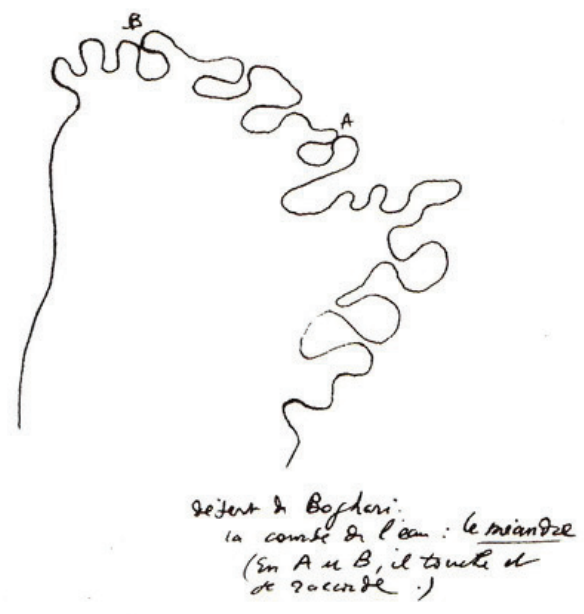

Fig. 5. Le Corbusier, Aircraft, (1935). Figure 122:

"Boghari desert. The water flow: The meander. At A and B connection points"
In order to recover harmony in the urban system and its balance with the natural medium, it was necessary to retrieve the rules followed by human establishments throughout history, disregarded by the machinist society and then perceived more clearly from above: "From then on, things are again within the human scope. Nature has been taken into consideration again. The city, instead of becoming an implacable block of stone, is a vast park where the planner will distribute housing units with corresonding size, real vertical communities" (Le Corbusier 1945:20).

In fact Le Corbusier's expeditious proposals were then applied to the territory. In his effort to create an abstract model to organise the planet surface, nature domesticated by man gained prominence, the kind of nature that had left its condition of wild to take on the role of new public space. A rational, comprehensible model, though able to admit the diversity and richness of the natural habitat under its wing. A malleable model (Fig. 8).

Geography took a leading role in the making of this new model and in defining the new public space, geography spoke and Le Corbusier listened: "geography has been begged to provide a first indication of a layout of a linear industrial city through the territory" (Le Corbusier 1945:130).

The analysis that the aerial view made possible allowed him to forcefully affirm that "human establishments" had spread all over the planet in a chaotic, catastrophic way as a result of the change in the territorial model introduced by the Industrial Revolution. The mid-twentieth century went through a deep crisis and the situation provoked a radical transformation of the spatial occupation model: "Human establishments must occupy the space in specifically assigned points, and its shape, originated from intrinsic values, is arranged in a true built biology. The study of

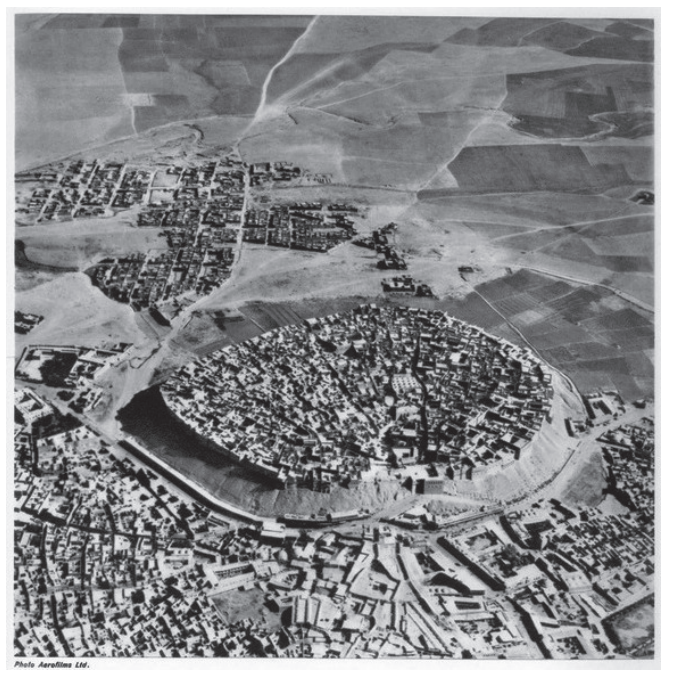

Fig. 6. Erbil (Irak) aerial view from Découverte aérienne du monde. Chombart de Lauwe, Paul; Crochet-Damais, Pierre; Marthelot, Pierre; Griaule, Marcel; Parent, Michel; Moraze, Charles; Schlienger, Georges. Paris : Horizons de France. 1948 


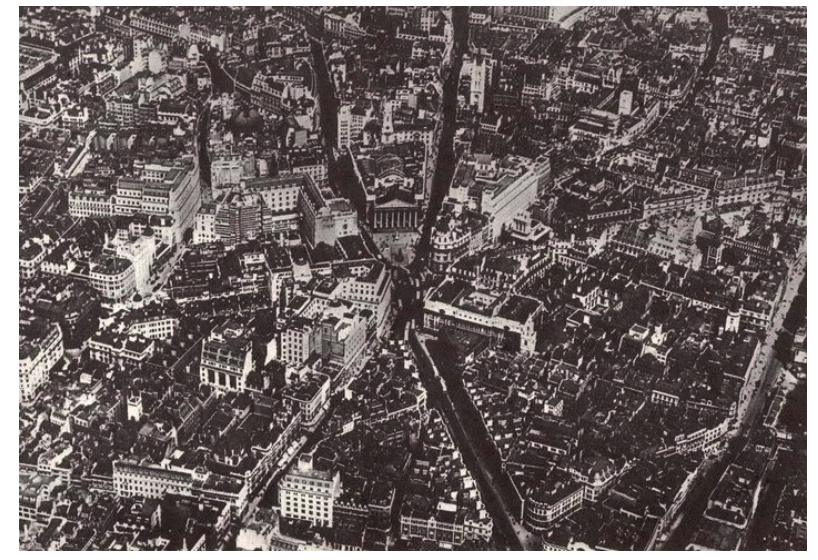

Fig. 7. Le Corbusier. Aircraft, (1935). Figure 102

these three types of establishments will allow us to progress towards certitudes. Space occupation can be reconsidered, which properly means: arrange the space, make human geography and geoarchitecture. Give these three establishments a statute, confer them a biology that takes into account the nature of the land which receives them and the nature of the men that will give them a soul, such is the desire in which we feel ourselves entitled to persevere" (Le Corbusier 1945:68).

This new understanding of the framework of the planet resulted in a model based on the clear definition of three keys which allowed arranging the territory in a balanced way: the agricultural operation unit, the industrial linear city and the radio-centric city of exchanges (Fig. 9). These were scientific proofs of what Le Corbusier gave the ambitious name of modern urban biology which offered rules, laws and criteria that took shape in easy principle schemes. However, as these schemes were supported and extended on a natural setting, they were eager to adopt risky organic morphologies recognising the qualities of a habitat over which they did not seem to prevail any more.

A new understanding of the territory lay under this adaptation process which Le Corbusier went through. Deformation of the new city's structure towards organic shapes was due to a clear accommodation to the richness (both natural and cultural) of the medium where those valuable places, which started to be recognised as natural parks, future museums of the territory, were destined to become the contemporary territory-city's backbone public space, a new carpet extending not only at the foot of the cities, but also all over the planet.

\section{Conclusion: a New Global Order through public space}

For Le Corbusier this was also the moment to strongly defend what could have been the main element of his discourse, with precedence over technique, aesthetic mutations or any other partial reason: "the absolute dissolution of all the limits bordering nations, groups, individuals

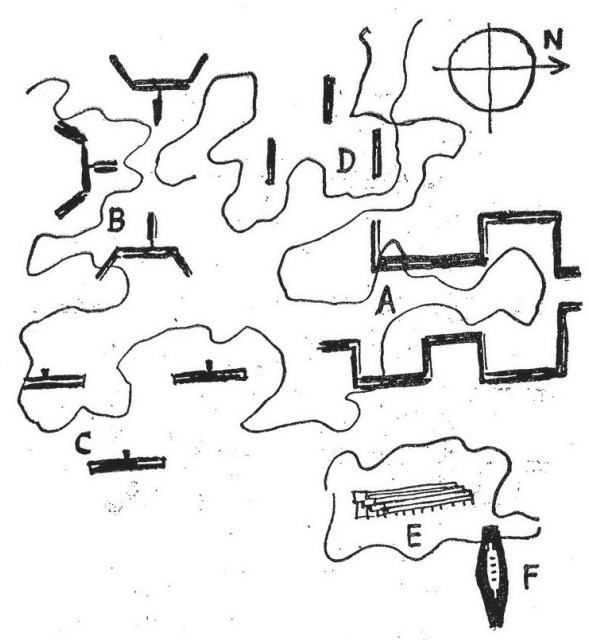

Fig. 8. Le Corbusier, Urbanisme des trois établissements humains (1945)

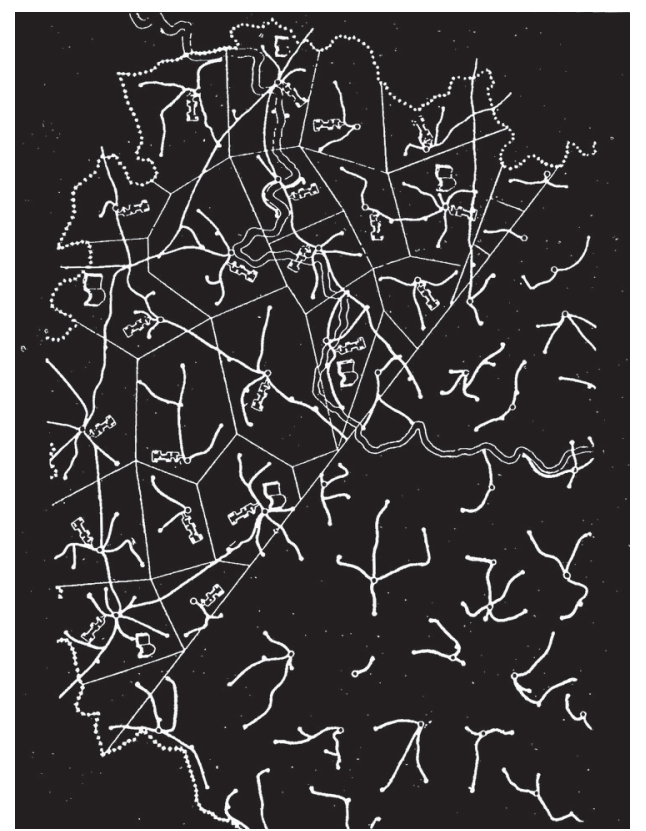

Fig. 9. Le Corbusier, Urbanisme des trois établissements humains (1945). Geoarquitecture, a particular version of Human Geography suggested by Le Corbusier.

or entities in the past" (Fig. 10) as Pancho Liernur has pointed out.

In those years, from the mid-twentieth century, the aircraft helped to establish the beginning of a New Global Order where human geography principles finally prevailed over the outdated approaches of the regional discipline. Less than forty years had passed since Le Corbusier heard Auguste Perret (1874-1954) say that thanks to aviation borders did not make sense any longer, scarcely twenty years since the texts published by Pratz, Giedion or Hitchcock started to build the "universal" character of modern architecture, but the vertiginous development of aeronautics would let more than two hundred million passangers plough through the planet by air every year from 1950 . 
Understanding of the planet began to have much more to do with a representation in isochronous lines than with conventional cartographies.

Aware of these realities, Le Corbusier devoted in Urbanisme des trois établissements humains a whole chapter to the aircraft and its effects on the development of civilisation. We can draw from it key principles which claim for the new role of flights. He insisted on a certitude already pointed out in Precisions a few years before, when he had categorically stated: "It seems to me that airline networks will become its efficient nervous system".

It is there, in drawing this nervous system, where those working on the territory - architects, urban planners, geographers, engineers, biologists,... politicians - must put all their interests. Among Le Corbusier's drawings, the most important ones were those in which the medium became global, like in Precisions, when he introduced a complete section about America or when he tried to explain Europe's new geography in Urbanisme des trois établissements humains (Fig. 11).

As Cristine Boyer has pointed out: "Le Corbusier resorted to his famous refrain 'the hour is striking': the time is favorable; now we absolutely must look ahead and plan for a world in which the aerial route will lie supreme". Besides, it came to no surprise to see this interest for aviation's capacity to build up a new communication network in the planet, just in a few years, those around the third and fourth decades of the twentieth century, in which Le Corbusier's political commitment, irrefutably shown in his participation in two neosyndicalist newspapers such as Plans (1931-1932) and Prélude (1933-1935), pushed him strongly towards those interests.

The greatest specificity in this sense was offered in the publication of "Urbanisme et aéronautique", an article

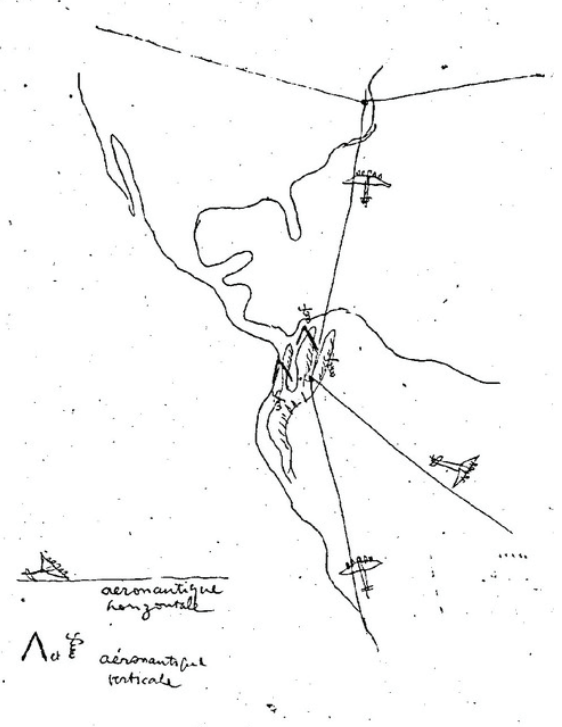

Fig. 10. Le Corbusier. "Urbanisme et aéronautique” (1947): „San Francisco-New York, París, Moscú, Bogotá, Santiago, Rio, Buenos Aires .a new human adventure" in the journal Techniques et Architecture, which devoted a whole issue to the topic in 1947. A significant part of Le Corbusier's short text was intended to gloss the spectacle of nature, unveiled in a new dimension thanks to the airplane, a new perspective that led him to highlight the value of the rural environment and how it was dramatically abandoned in the industrial civilisation. He also verified how the establishment of a new territorial network, due to the freedom to circulate then allowed by aviation, represented a great opportunity to revitalise that worthy but marginalised territory by means of a complete process of reinventing the space occupation model: "This map of Europe, for example, shows international ways of work and exchange that leave between them vast peasant áreas and vast natural reserves; [...]. Here Aviation prepares, with the helicopter, the closest way to revitalize the countryside" (Le Corbusier 1947: 464).

By analysing the illustrations included in "Urbanisme et aéronautique" we can understand how at this point the presence of aircraft over the cities started to generate doubts in Le Corbusier, who, twenty years before, had planned the airport in the very heart of his Ville Contemporaine without hesitation. Then, in Urbanisme et Aéronautique, he chose a picture by Buonamico Buffalmacco (1290-1340) to equate the heights of the modern city with a strained sky, full of angels and demons (Fig. 12).

After his extensive personal experience with flights and their scope, Le Corbusier understood the need to place the airport away from the city and discreetly fit it within the landscape, by writing: "The beauty of the airport, this is the splendor of space!". Thus, in the drawings published in "Urbanisme et aéronautique" and Urbanisme des trois établissements humains the terminal was not the huge temple of machinist mobility anymore and became a simple line

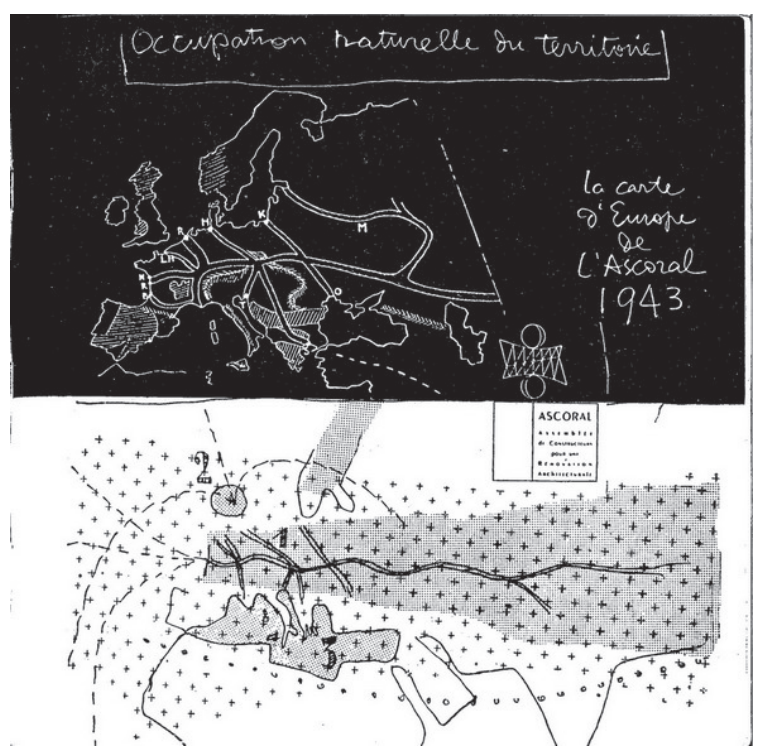

Fig. 11. Le Corbusier. Urbanisme des trois établissements humains (1945). ASCORAL European Chart. New guidelines for the euroopean landscape 


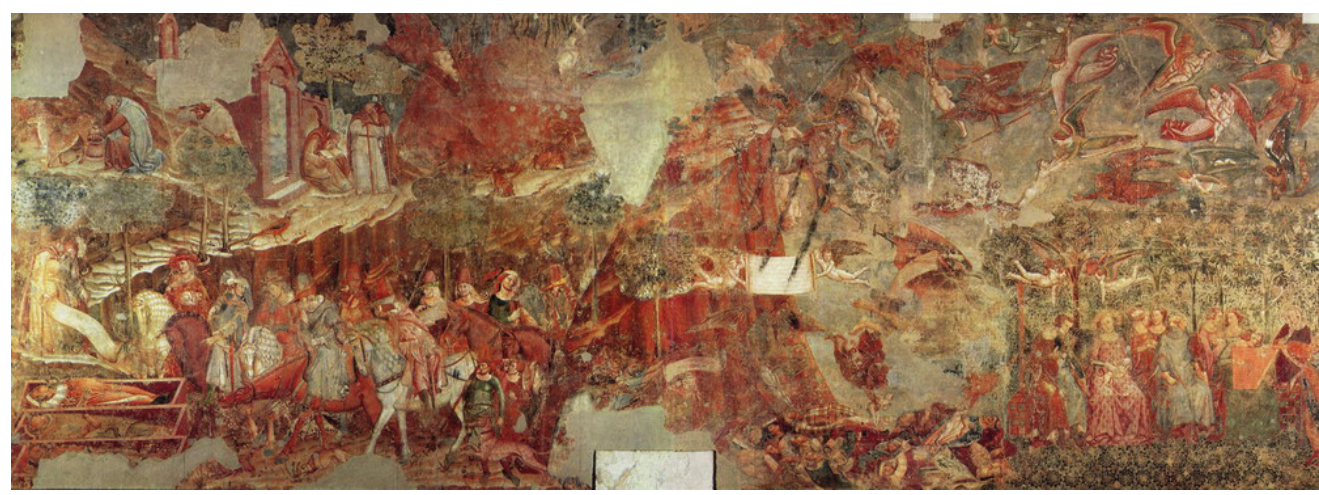

Fig. 12. Il Triunfo della Morte. Buanamico Buffalmaco (1290-1341). Le Corbusier got a part of this fresco as illustration in „Urbanisme et aéronautique" (1947) with the text: "We have already experienced the Paris sky filled by the sound of fourengined planes. Each time one of them passed through my roof garden, we had to stop talking ..."

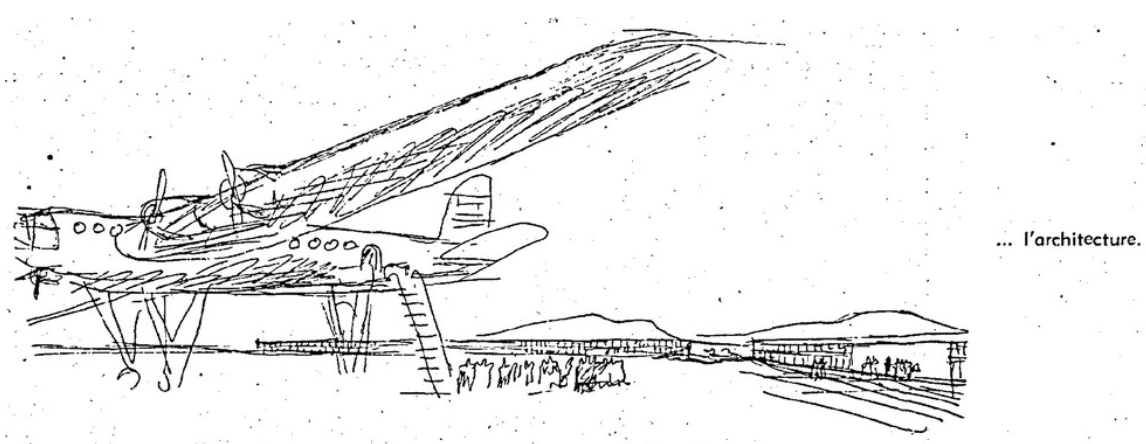

Fig. 13. Le Corbusier. "Urbanisme et aéronautique" (1947) Terminal building is just a single line in the horizon

in the horizon (Fig. 13), hardly perceptible, also subdued by the strength of the landscape, by the construction of that new habitat where natural and human interwine.

\section{References}

Boyer, M. C. 2003. Aviation and the aerial view: Le Corbusier's spatial transformations in the 1930s and 1940s', Diacritics 33 (3/4): 93-116. http://dx.doi.org/10.1353/dia.2006.0004

Brenner, N; Schmid, C. 2015. Towards a new epistemology of the urban?, City 19 (2-3): 151-182.

http://dx.doi.org/10.1080/13604813.2015.1014712

Brunhes, J. 1910. La géographie humaine. Essai de classification positive. Principes et exemples. Paris: Alcan.

Bunkse, E. 1990. Saint-Exupéry's geographic lesson: art and science in the creation and cultivation of landscape values, in Annals of the Association of American Geographers 80(1): 96108. http://dx.doi.org/10.1111/j.1467-8306.1990.tb00005.x

Cohen, J. L. 1993. De l'oral à l'écrit:PRÉCISIONS et les conferences latinoaméricaines de 1929, in Le Corbusier, écritures. Fondation Le Corbusier, París, 30-41.

Collins, C. 1995. Urban interchange in the Southern Cone: Le Corbusier (1929) and Werner Hegemann (1931) in Argentina, Journal of the Society of Architectural Historians (June).

Colomina, B. 1994. Privacy and publicity: modern architecture as mass media. Cambridge: MIT Press.
De Maria, L. (Ed). 1968. Teoria e invenzione futurista, Fillipo Tomaso Marinetti. Milan: Mondadori.

Duempelmann, S. 2010. Between science and aesthetics. Aspects of "Air-minded" landscape architecture, Landscape Journal 29: 161-178. http://dx.doi.org/10.3368/lj.29.2.161

Duempelmann, S. 2014. Flights of imagination: aviation, landscape, design. Charlottesville: University of Virginia Press.

Framptom, K. 1980. Modern architecture; a critical history. London: Thames and Hudson.

Gerber, A. 1992. L’Algérie de Le Corbusier: les voyages de 1931. Thèse Ecole polytechnique fédérale de Lausanne EPFL, No. 1077 (1992).

Gutiérrez, R.; (Ed), 2009. Le Corbusier en el Río de la Plata, 1929. Buenos Aires: CEDODAL.

Gutiérrez, R.; González, N. 2009. Hace 80 años, Le Corbusier en Asunción. $a b c$ (Asunción, Paraguay) August 2th.

Humboldt, A. 1845-1862. Cosmos. New York.

Kafka, F. 1909. Die aeroplano in Brescia. Praga: Bohemia.

Le Corbusier. 1930. Précisions sur un état présent de l'architecture et de l'urbanisme. París: G. Cres.

Le Corbusier. 1931. Détours...o l'enseignement du voyage. Coupe en travers: Espagne, Maroc, Algérie, Territoires du Sud, Plans 8: 92.

Le Corbusier. 1935. Aircraft. London: Studio Publications.

Le Corbusier. 1941. Sur les quatro routes. Paris: Gallimard.

Le Corbusier. 1945. Urbanisme des trois établissements humains. Paris: Forces Vives aux Éditions de Minuit. 
Le Corbusier. 1947. Urbanisme et aéronautique, Techniques et Architecture VII (9-12): 463-467.

Liernur, P. 2008. La red austral: obras y proyectos de Le Corbusier y sus discípulos en la Argentina (1924-1965). Bernal: Universidad Nacional de Quilmes.

Maderuelo, J. 2008. La Construcción del Paisaje Contemporáneo. Huesca: CDAN

Marinetti, Filippo T. 1968. Teoria e invenzione futurista, Milan: Mondadori, p. 136.

Monteys, X. (Ed). 2004. Le Corbusier y el paisaje, Massilia 2004 bis. Barcelona: UPC

Morshed, A. 2015. Impossible heights: skyscrapers, flight, and the master builder. Minneapolis, MN: University of Minnesota Press. http://dx.doi.org/10.5749/minnesta/9780816673186.001.0001

Pedretti. B. 1987. Il volo dell'etica, Casabella 531-532: 74-80

Rojo de Castro, L. 2008. [Ideogramas] Precisiones sobre Precisiones, Revista de Arquitectura 10: 35-48.

Sachs, A. 1995. Humboldt's legacy and the restoration of science, World Watch 8: 28.

Sequeira, M. 2012. Para um espaço público. Le Corbusier e a tradiçao greco-latina na cidade moderna. Fundaçao Calouste Gulbekian Fundaçao para a Ciência e a Tecnologia, Lisboa.

Tsiomis, Y. 1998. Le Corbusier, Rio de Janeiro 1929-1936. Centro de Arquitectura e Urbanismo do Rio de Janeiro, Rio de Janeiro.
Waldheim, Ch, Duempelmann, S. (Eds.) 2016. Airport landscape: urban ecologies in the aerial age. Harvard University Graduate School of Design, Cambridge, MA.

\section{RAMÓN PICO}

Associate Professor of Contemporary History and Landscape Studies at the School of Architecture in Seville University. Has been fostering a parallel design practice and research activity, focused on the historical intersections of architecture, landscape and urbanism, through experiences as Visiting scholar at Harvard GSD, Lunds Tekniska Högskola (Sweden), École D’Architecture de Nancy (France), Politecnico di Milano (Italy), Tongji University (Shanghai) and SWUST (Miangyang).

Active member of DoCoMoMo in Spain, lecturing and exhibiting at many universities and conferences, including the 3rd European Landscape Biennale (First Prize), 7th Spanish Biennale and Ibero-American Architecture Biennale. His works and writings have been published in journals as El Croquis, Bauwelt, Lotus, Garten + Landschaft or Detail. 